\title{
DERECHOS DE LOS AGRICULTORES Y CONVENIO UPOV/9I
}

MARTÍN URIBE ARBELÁEZ*

\section{Prolegómenos}

Los portentosos avances de la biotecnología han permitido acelerar la obtención de nuevas variedades de plantas e incluso diseñarlas, mediante la recombinación de genes, para hacerlas resistentes a plagas específicas e incrementar su productividad. Bien sea mediante técnicas de ADN o por medio de biotecnología convencional, la protección de la materia viva, capaz de reproducirse, plantea el reto de cómo proteger esta innovación. ¿Es preciso cercar estas nuevas variedades o especies de plantas con derechos de exclusividad y sanciones penales en caso de infracción, porque de lo contrario no habría protección? ¿Cómo conciliar el interés privado por una protección a ultranza con el beneficio social?

Téngase en cuenta que aquí se está hablando de propiedad intelectual sobre semillas y que gran parte de ellas constituyen la base de la alimentación de todos los seres humanos, poco más de 7.200 millones de personas en el mundo, “y se espera que para 2050 habrá aumentado más de 2.000 millones" ${ }^{1}$.

La biotecnología vegetal se promueve como la única forma de conjurar la profecía malthusiana, haciendo a un lado que el problema en la actualidad no es la falta de alimento sino su disponibilidad y acceso.

* Profesor asociado de la Facultad de Derecho, Ciencias Políticas y Sociales de la Universidad Nacional de Colombia y profesor de la Especialización en Propiedad Industrial, Derechos de Autor y Nuevas Tecnologías de la Universidad Externado de Colombia. Magíster en Biociencias y Derecho de la Universidad Nacional de Colombia. Abogado de la Universidad Externado de Colombia. Contacto: [maruribe2000@yahoo.com.mx]. Fecha de recepción: 2 de marzo de 2016. Fecha de aceptación: 27 de julio de 2016. Para citar el artículo: Uribe Arbeláez, M. Derechos de los agricultores y Convenio upov/91. Revista La Propiedad Inmaterial n. ${ }^{\circ}$ 21, Universidad Externado de Colombia, enero-junio 2016, pp. 139-171. DOI: http://dx.doi.org/10.18601/16571959.n21.06.

1. Naciones Unidas, La situación demográfica en el mundo, 2014, Departamento de Asuntos Económicos y Sociales, División de Población, New York, 2014, p. III, disponible en [www.un.org/en/development/desa/population/publications/pdf/trends/Concise\%20Report\%20on\%20 the\%20World\%20Population\%20Situation\%202014/es.pdf], recuperado el 23 de marzo de 2016. 
... actualmente se produce más alimento del necesario para alimentar a los siete mil millones de personas que viven hoy día en el planeta. Y sin embargo, dos mil millones de personas sufren de malnutrición crónica o desnutrición [...]

[...] precisamente la mayor contribución de [Amartya] Sen fue mostrar que el grave problema del alimento no está en el suministro sino en el acceso, no en la producción per se, sino en la justicia ${ }^{2}$.

Por otra parte, del hecho de que sean semillas genéticamente modificadas (OGM) no se sigue de suyo que tengan rendimiento y resistencia mayores garantizados. Lo sucedido con el algodón Bt ejemplifica el aserto. En el año 2008 los algodoneros del Tolima perdieron entre el 50 y el $75 \%$ de la cosecha, lo que les significó un detrimento de veinte mil millones de pesos aproximadamente y afectó a más de mil productores. En 2009 también se presentaron serios problemas con el algodón $\mathrm{Bt} / \mathrm{RR}$, en los departamentos de Córdoba y Sucre, pero lo más increíble fue que "el algodón transgénico obtuvo un rendimiento de $1.762 \mathrm{~kg} / \mathrm{ha}$, mientras que el algodón no transgénico llegó hasta $2.027 \mathrm{~kg} / \mathrm{ha”}$.

Vandana Shiva ha formulado graves denuncias por las consecuencias negativas derivadas de la utilización de dicho algodón transgénico: "Los anuncios publicitarios de Monsanto prometían a los agricultores cosechas de 15 quintales de algodón por acre y 226 dólares de ingresos adicionales. Sin embargo, para muchos agricultores el algodón Bt fracasó totalmente. En la temporada 2005, los agricultores de Vidharba, Maharashtra, perdieron toda la cosecha" ${ }^{4}$.

Más allá de la polémica en torno al uso o no de las semillas genéticamente modificadas, que en el fondo revive la controversia sobre la patentabilidad de la materia viva ${ }^{5}$, lo cierto es que su uso continúa extendiéndose, al punto que en 2014 se alcanzó la cifra récord de 181.5 millones de hectáreas de cultivos transgénicos.

... un aumento de 6 millones de hectáreas con respecto a 2013, de acuerdo con el informe publicado hoy por el Servicio Internacional de Adquisición de Aplicaciones de Agrobiotecnología (ISAAA, por su sigla en inglés) [...] [U]n total de 28 países cultivaron

2. Rieff, David. El oprobio del hambre. Alimentos, justicia y dinero en el siglo XXI, Bogotá, Taurus, 2016, pp. 198-199.

3. Vélez, Germán. "Colombia: Una evaluación de los cultivos genéticamente modificados en Colombia”, en La ecología politica de la bioseguridad en América Latina, Toro Pérez, Catalina; Bravo, Elizabeth y Vélez, Germán (eds.), Bogotá, Universidad Nacional de Colombia, 2014, pp. 142-143.

4. Shiva, Vandana. "El algodón Bt de la empresa estadounidense Monsanto ha empujado a miles de agricultores indios al endeudamiento, la desesperación y la muerte”, Red de Acción en Plaguicidas y sus Alternativas para América Latina (RAP-AL) Uruguay, disponible en [www.rapaluruguay.org/transgenicos/Algodon/algodonBT.India.html], recuperado el 24 de marzo de 2016.

5. Cfr. Uribe Arbeláez, Martín. Propiedad Industrial, neoliberalismo y patente de la vida, Bogotá, Doctrina y Ley, 2002, y La transformación de la Propiedad Intelectual, Bogotá, Doctrina y Ley, 2005. 
transgénicos durante el año. Los 20 países desarrollados y los 8 países en vías de desarrollo donde se cultivan transgénicos representan más del 60\% de la población mundial ${ }^{6}$.

Empero, ello no quiere decir que se escamoteen sus riesgos y falencias, ni el hecho de que un puñado de compañías multinacionales controlen el mercado global ${ }^{7}$. Tampoco existe certeza sobre la inocuidad de los OGM, y los estudios que alertan sobre efectos nocivos para la salud son descalificados en forma acre ${ }^{8}$. Lo increíble es que a estas alturas no haya un estudio imparcial y cuyo rigor objetivo sea incuestionable, que demuestre la completa inocuidad de los ogm. Por lo tanto, el principio de precaución ${ }^{9}$ debe seguir aplicándose con rigurosidad, al igual que el inalienable derecho de los consumidores a la información y libre elección. Así lo dispuso la Corte Constitucional al considerar que los alimentos transgénicos deben estar etiquetados, lo que exige la Unión Europea desde hace años ${ }^{10}$ : "La Corte determinó que en la información mínima que debe suministrarse al consumidor de un producto alimenticio, según lo que establezca la ley, deberá especificar si se trata de alimentos transgénicos o modificados genéticamente o el porcentaje de componentes de organismos genéticamente modificados (OGM) que contenga. Para tal efecto, se concedió al Congreso el término de dos años"11.

Ojalá que el Congreso así lo haga, porque la Resolución 4254 del 2011 $1^{[12]}$ expedida por el entonces Ministerio de la Protección Social, hoy Ministerio de Salud,

6. ISAAA, International Service for the Acquisicion of Agri-Biotech Applications. "Los cultivos transgénicos muestran un crecimiento constante; beneficios obtenidos en 2014; la superficie sembrada en todo el mundo aumentó en 6 millones de hectáreas”. Disponible en [www.isaaa.org/resources/publications/briefs/49/pressrelease/pdf/B49-PressRelease-Spanish.pdf], recuperado el 24 de marzo de 2016.

7. "Solo seis empresas transnacionales -Monsanto, DuPont, Syngenta, Dow, Bayer, Basf- controlan el $100 \%$ de las semillas transgénicas cultivadas en el mundo, y todas son originalmente fabricantes de químicos": Ribeiro, Silvia. "Asalto corporativo a las semillas", етс Group, 20 de mayo de 2014. Disponible en [www.etcgroup.org/es/content/ asalto-corporativo-las-semillas], recuperado el 24 de marzo de 2016.

8. "El estudio encontró daño severo al hígado y riñón y desórdenes hormonales en ratas alimentadas con el maíz GM y bajos niveles de Roundup, los cuales están por debajo de los permitidos en el agua potable de la Unión Europea. Se encontraron efectos tóxicos del maíz GM analizado por sí solo tanto como del Roundup analizado por sí solo y junto al maíz. Descubrimientos adicionales inesperados fueron las altas tasas de tumores de gran tamaño y mortalidad en la mayoría de grupos de tratamiento": "Republicación del estudio de Séralini: La ciencia habla por sí misma”, 24 de junio de 2014, Ignacia Guzmán Zuloaga (trad.), en GMoSeralini, disponible en [www.gmoseralini.org/republicaciondel-estudio-de-seralini-la-ciencia-habla-por-si-misma/], recuperado el 24 de marzo de 2016.

9. Cfr. Protocolo de Cartagena sobre Seguridad de la Biotecnología del Convenio sobre la Diversidad Biológica, aprobado mediante la Ley 740 de 2002. Disponible en [www. secretariasenado.gov.co/senado/basedoc/ley_0740_2002.html], recuperado el 24 de marzo de 2016.

10. Reglamentos (CE) 1829 de 2003 y 1830 de 2003. Disponibles en [http://eur-lex. europa.eu/legal-content/ES/TXT/?uri=URISERv:121154], recuperado el 24 de marzo de 2016.

11. Sentencia C-583 de 2015, M.P.: Gloria Stella Ortiz Delgado. Corte Constitucional, Comunicado n. ${ }^{\circ} 39,8$ de septiembre de 2015, disponible en [www.corteconstitucional. gov.co/comunicados/No.\%2039\%20comunicado\%2008\%20de\%20septiembre\%20de\%202015.pdf], recuperado el 24 de marzo de 2016.

12. Disponible en [www.invima.gov.co/images/pdf/normatividad/alimentos/resoluciones/resoluciones/2013/resolucion\%204254\%20de2011.pdf, recuperado el 16 de abril de 2016. 
es tan laxa que en últimas no obliga al etiquetado de los alimentos transgénicos, exigiéndolo sólo cuando "no sean sustancialmente equivalentes con su homólogo convencional”. Esta equivalencia sustancial se establece por la composición nutricional del alimento y la "forma de almacenamiento, preparación o cocción", que debe ser diferente a la del convencional, o cuando los alimentos "contengan un solo ingrediente o aditivo producido por Microorganismos Genéticamente Modificados"13. Por manera que el etiquetado, en vez de ser la regla general, se convierte con esta resolución en un evento excepcional.

Como se advierte, el problema es bastante complejo y con múltiples aristas que no se pueden soslayar, debiéndose también indicar los no menos graves efectos de la pérdida de biodiversidad por la uniformidad en los cultivos, que a su vez los torna susceptibles a otros tipos de plagas, así como la dependencia alimentaria al quedar condicionados los cultivadores a los productores de semillas, en su gran mayoría compañías biotecnológicas multinacionales.

Desde el ámbito estricto de la propiedad intelectual, interesa destacar el choque entre los privilegios de los obtentores o fitomejoradores y las ancestrales costumbres campesinas, verdadero derecho consuetudinario que sería cercenado para proteger a ultranza tales prerrogativas. ¿Es posible conciliar los derechos del obtentor con los del agricultor? O por el contrario, ¿la innovación biotecnológica debe imponerse para asegurar el retorno del capital invertido en la investigación y estimularla para la mejora de la productividad agrícola? ¿Cómo equilibrar ambos derechos? ${ }^{? 14}$.

\section{Derecho consuetudinario CAmpesino y Despojo de Plantas}

Las semillas son organismos maravillosos. Al plantarse se consumen, pero no mueren sino que se renuevan, "dando a luz" reemplazos centuplicados de la semilla original.

[...] Pero como para las grandes empresas, siempre ansiosas de encontrar nuevos nichos de crecimiento y ganancia, no hay obstáculo que las limite, analizaré [...] las formas de control que ejercen para superar dichas barreras. Estas son al día de hoy, de tipo tecnológico-biológico (semillas híbridas y transgénicas); de tipo legal (ej. las leyes de propiedad intelectual y las de liberalización, certificación y control de calidad de las semillas); y, por último de tipo contractual. Todas estas formas de dominio, aunque propiciadas por las grandes empresas semilleras y de investigación son así mismo facilitadas e impulsadas por los estados para apoyar el flujo y ampliación del capital en la

13. Ministerio de la Protección Social (actual MinSalud), Resol. 4524 de 2011, art. 4.

14. El presente artículo se apoya en parte en la investigación inédita dirigida por el autor, intitulada "Propiedad Intelectual sobre Semillas: upov - Derechos de los Agricultores", realizada por el grupo de investigación "Derecho y Desarrollo: Prometeo", adscrito a la Unidad de Investigaciones Jurídico Sociales Gerardo Molina (unijus) de la Facultad de Derecho, Ciencias Políticas y Sociales de la Universidad Nacional de Colombia. 
agricultura. Los controles simple y llanamente intentan impedir, de diversas maneras, que el agricultor produzca, intercambie y mejore indefinidamente la semilla que siembra y multiplica sin necesidad de comprarla cada año ${ }^{15}$.

Desde los albores de la civilización, cuando el ser humano se hizo sedentario y surgió la agricultura, ha sido una inveterada costumbre recolectar semillas, seleccionarlas, limpiarlas, guardarlas e intercambiarlas. La paciente y perseverante labor permitió domesticarlas, adaptarlas y mejorarlas. Así por ejemplo, se domesticaron especies silvestres como el arroz, originario de China, que de allí paso a India y Japón, donde se cruzó con variedades locales ${ }^{16}$.

Baste evocar lo acontecido con el café, cultivo emblemático que sustentó la economía colombiana durante gran parte del siglo xx y aún continúa haciéndolo. Originario de Egipto, Abisinia, en especial de Kaffa, de donde pasó a Arabia, tras siglos de intercambio y expansión llegó a Francia y luego a América ${ }^{17}$. En 1905 el general Rafael Uribe Uribe, nombrado por la administración de Rafael Reyes ministro plenipotenciario ante los gobiernos de Chile, Argentina y Brasil, remite a Colombia "selecciones de muchas semillas como la del 'café maragogipe', de la papa 'Cruz', la del maíz 'Guavito', del trigo 'Arrocero’ y ‘Oregón’ (llamado aquí 'Uribe'), del pasto 'yaraguá'” 18.

El cultivo del café generó una gran transformación social en la Colombia finisecular y durante las primeras décadas del siglo xx, estructurando una economía campesina conformada en gran parte por pequeña y mediana propiedad que apoyó la aparición de industrias orientadas a la satisfacción de las necesidades del mercado interno, proveyendo la demanda para esta producción.

Antioquia, que había vivido en las vertientes de las cordilleras central y occidental, se familiariza pronto con la producción y el cultivo del café. En la región de Fredonia se había hecho un ensayo feliz. En la cordillera central se ocupan también las regiones del Tolima. Se fundan poblaciones que luego adquirirán gran progreso. Surgen las ciudades del Fresno y del Líbano. De Manizales la onda humana se dirige al occidente. Se coloniza el feraz Quindío. En esta región se dan hechos que jamás se habían realizado en Colombia. Hay poblaciones que rápidamente se transforman. Pereira, Armenia, Calarcá, etc., pocos años después de haber sido fundadas, ofrecen un desarrollo impre-

15. Rodríguez Cervantes, Silvia. "El control corporativo de las semillas y sus consecuencias más allá de la agricultura”, en La ecología política de la bioseguridad en América Latina, cit., p. 59.

16. Cfr. ArgenBio, Consejo Argentino para la Información y el Desarrollo de la Biotecnología. "El arroz se originó en China”, abril 5 de 2011. Disponible en [www.argenbio. org/index.php?action=notas\&note=5627], recuperado el 25 de marzo de 2016.

17. Cfr. de Narváez, Enrique. "Historia del café", conferencia, en Biblioteca virtual Luis Ángel Arango, "Origen del café". Disponible en [www.banrepcultural.org/blaavirtual/ modosycostumbres/homca/homca03.htm], recuperado el 29 de marzo de 2016.

18. Santa, Eduardo. Rafael Uribe Uribe, Bogotá, Planeta, 1998, p. 344. 
sionante [...] en el departamento del Valle del Cauca se contemplan acontecimientos idénticos. Hay una población, Sevilla, que simboliza el progreso que en esa región produce también el café19.

Esta es una importante lección histórica que parece olvidada pero que reafirma la necesidad de que por fin se haga la hasta hoy truncada reforma agraria. La base de un desarrollo democrático, autopropulsado por la sinergia que brinda la demanda de consumidores solventes, sólo se consigue con un país de propietarios y no de peones o jornaleros asalariados.

... la extensión del área colonizada y sobre todo el gran número de personas vinculadas a la agricultura, hacían imposible que esta fuera comercializada con base en cultivos internos. Para el desarrollo era necesaria una demanda exterior, la cual se presentó con el café. Se dio entonces un hecho desconocido hasta el momento en el país: el surgimiento de un gran número de pequeños propietarios, trabajadores ellos mismos de sus parcelas y productores para el mercado mundial. Antes los otros productos agrícolas de exportación habían beneficiado a unos pocos solamente. El tabaco, el algodón o el añil, por ejemplo, se habían explotado en beneficio de un reducido número de terratenientes, y al pasar su auge sólo quedaron grandes dehesas para ganado y una vasta masa de asalariados que habían consumido lo ganado en jornales. Con la producción cafetera en las condiciones del occidente se aumentaron la capacidad adquisitiva y el mercado, pues no sólo creció la ocupación, sino que la distribución del excedente producido fue más democrática ${ }^{20}$.

La libre circulación de semillas ha sido una constante a lo largo de la historia de la humanidad. De igual modo la selección y mejoramiento de semillas que han realizado las comunidades campesinas desde tiempos inmemoriales, así como su intercambio y venta en mercados locales. Hay que destacar que además de este ancestral derecho de paisanaje, el tradicional mercado tiene una importancia vital para las comunidades campesinas y fue por ello que, para sintetizar su trascendencia, el día viernes 20 de julio fue el escogido para desencadenar la reyerta que sería el grito de independencia, "fecha en que la Plaza Mayor estaría colmada de gentes de todas las clases sociales, por ser el día habitual de mercado" ${ }^{21}$.

19. Nieto Arteta, Luis Eduardo. Ensayos sobre economía colombiana, Medellín, Oveja Negra, 1969, pp. 43-44.

20. Tirado Mejía, Álvaro. Introducción a la historia económica de Colombia, Medellín, La Carreta, 1976, p. 192.

21. Liévano Aguirre, Indalecio. Los grandes conflictos sociales y económicos de nuestra historia, t. III, Bogotá, Nueva Prensa, 1960, p. 136. 


\section{A. Tratado internacional sobre los Recursos Fitogenéticos PARA LA ALIMENTACIÓN Y LA AGRICULTURA}

El TIRFAA fue adoptado en noviembre de 2001 por la Conferencia de la FAO (Organización de las Naciones Unidas para la Agricultura y la Alimentación), y entró en vigor el 29 de junio de 2004, noventa días después de que cuarenta Estados lo hubieren ratificado ${ }^{22}$. Dentro de los países que lo han ratificado figuran: Alemania, Australia, Bélgica, Brasil, Canadá, Costa Rica, Ecuador, España, Francia, Guatemala, Honduras, India, Indonesia, Italia, Japón, Kenia, Malasia, Nicaragua, Noruega, Países Bajos, Panamá, Paraguay, Perú y Venezuela, entre otros ${ }^{23}$.

Colombia, si bien es signatario desde el 30 de octubre de 2002, no lo ha ratificado. Igual sucede con Estados Unidos que lo suscribió el 1 de noviembre de 2002 pero tampoco ha procedido a su ratificación ${ }^{24}$. No obstante que, en consecuencia, carece de fuerza vinculante y forma parte de lo que se conoce como soft law, el TIRFAA no es inane o irrelevante para la juridicidad colombiana.

... Este derecho blando sirve para evidenciar una costumbre internacional y como guía interpretativa de los instrumentos convencionales, y en cuanto tal es muy útil ya que su contenido es más preciso, especializado y detallado que el de los TIDH [...]

[...] La Corte Constitucional ha usado este derecho blando (soft law) de dos maneras: en primer lugar, como herramienta interpretativa en varios de sus pronunciamientos; en segundo lugar, incorporando al Bloque de Constitucionalidad los apartes de estos instrumentos que desarrollan normas de los TIDH y del DIH que forman parte del bloque, convirtiendo instrumentos de derecho blando (soft law) del derecho internacional en derecho duro (hard law) en el orden interno ${ }^{25}$.

Para el objeto de estudio, interesa subrayar que el TIRFAA recoge el derecho consuetudinario campesino o la inveterada y ancestral costumbre de seleccionar, limpiar, guardar, intercambiar y vender semillas, consagrando:

22. FAO. Tratado Internacional sobre los Recursos Fitogenéticos para la Alimentación y la Agricultura. Disponible en [www.planttreaty.org/es/list_of_countries], recuperado el 25 de marzo de 2016.

23. омpi, Organización Mundial de la Propiedad Intelectual. Tratado Internacional sobre los Recursos Fitogenéticos para la Alimentación y la Agricultura, "total partes contratantes: 138". Disponible en [www.wipo.int/wipolex/es/other_treaties/parties.jsp?treaty_ id=255\&group_id=22], Recuperado el 25 de marzo de 2016.

24. Ibíd.

25. López Medina, Diego Eduardo y Sánchez Mejía, Astrid Liliana. "La armonización del derecho internacional de los derechos humanos con el derecho penal colombiano", International Law, Revista Colombiana de Derecho Internacional, n. ${ }^{\circ} 12$, Universidad Javeriana, enero-junio de 2008. Disponible en [www.scielo.org.co/scielo.php?script=sci_arttext\&pid=S1692$81562008000100012 \#$ nu46], recuperado el 25 de marzo de 2016. 
Artículo 9 - Derechos del agricultor

[... 9.3 Nada de lo que se dice en este Artículo se interpretará en el sentido de limitar cualquier derecho que tengan los agricultores a conservar, utilizar, intercambiar y vender material de siembra o propagación conservado en las fincas, con arreglo a la legislación nacional y según proceda ${ }^{26}$.

La remisión a la legislación nacional, que en sana lógica está orientada a tutelar estos derechos y no a desconocerlos, pone de manifiesto la falta de un mecanismo de coerción a nivel internacional, en forma muy diferente a lo que se dispuso en el caso de la Organización Mundial del Comercio (OMC), que sí cuenta con un Órgano de Solución de Diferencias cuyas decisiones son de carácter obligatorio para los países miembros. Otro tanto ocurre con los contratos de estabilidad jurídica y garantías de la inversión, o con los TLC, "acuerdos de promoción comercial”, en los que sí se dispone de forzosos tribunales de arbitramento ${ }^{27}$.

El TIRFAA también se queda corto en la protección de los recursos fitogenéticos de los países en desarrollo, ricos en biodiversidad, y no previene la posibilidad de apropiación vía patentes de productos derivados o incluso de los genes individualmente aislados. Aquí también se imponen la geopolítica y la conocida relación centro-periferia.

\section{B. Decisión 345 De 1993}

La norma comunitaria andina, "Régimen Común de Protección a los Derechos de los Obtentores de Variedades Vegetales" ${ }^{28}$, recoge la tradicional costumbre campesina de seleccionar, limpiar, conservar, guardar o almacenar, intercambiar y vender semillas. En su artículo 26 prescribe:

No lesiona el derecho de obtentor quien reserve y siembre para su propio uso, o venda como materia prima o alimento el producto obtenido del cultivo de la variedad protegida. Se exceptúa de este artículo la utilización comercial del material de multiplicación,

26. TIRFAA, artículo 9 - Derechos del agricultor, bastardillas fuera de texto. Disponible en [ftp://ftp.fao.org/docrep/fao/011/i0510s/i0510s.pdf], recuperado el 25 de marzo de 2016.

27. "Bajo estos sistemas de arbitraje de diferencias Estado-inversor (ISDs, por sus siglas en inglés: investor-State dispute settlement), los inversionistas extranjeros adquieren nuevos derechos para demandar a los gobiernos nacionales en arbitraje privado vinculante en caso de que se instituyan reglamentos que ellos consideran como un factor que disminuye la rentabilidad esperada de sus inversiones. [...] [L]a obligación de compensar a los inversores por pérdidas de ganancias esperadas puede y se ha aplicado incluso cuando las reglas no son discriminatorias y las ganancias se obtienen causando daños a la comunidad": Stiglitz, Joseph E. "La farsa del TPP", en El Espectador, 10 de octubre de 2015. Disponible en [www.elespectador.com/opinion/farsa-del-tpp], recuperado el 25 de marzo de 2016.

28. Decisión 345 de 1993. Disponible en [www.wipo.int/wipolex/es/text.jsp?file_id=223071], recuperado el 26 de marzo de 2016. 
reproducción o propagación, incluyendo plantas enteras y sus partes, de las especies frutícolas, ornamentales y forestales.

El derecho de paisanaje de intercambiar semillas entre vecinos no está expreso en la precitada disposición, y tampoco la venta de semillas en el mercado local que, se insiste, es una costumbre ancestral de la economía campesina. Pero conforme a la más elemental hermenéutica y aplicando el viejo aforismo de que "el que puede lo más, puede lo menos", el derecho de paisanaje de intercambiar semillas está implícito en la transcrita disposición. La norma es muy clara en el derecho que les asiste a los agricultores de guardar y resembrar las semillas o vender "como materia prima o alimento el producto obtenido del cultivo de la variedad protegida". Esto no es una ocurrencia caprichosa sino una importante salvedad que se hace en ejercicio de la amplia discrecionalidad que le confiere a los Estados el Convenio upov de $1978^{[29]}$, del cual los países andinos son parte, y que se restringe o cercena en la versión upov de 1991 al hipertrofiar los derechos del obtentor hasta abarcar el "producto de la cosecha" ${ }^{30}$ y a "productos fabricados directamente a partir de un producto de cosecha de la variedad protegida" 31.

La Decisión 345 de 1993 en su artículo 26 extiende la protección de los derechos del obtentor a las partes de las plantas o sus productos, en la medida en que puedan ser usados como material de reproducción o propagación, pero única y exclusivamente en tratándose de plantas ornamentales, frutícolas y forestales. La regla general es que en todos los demás casos-siempre y cuando no se trate de plantas ornamentales, frutícolas o forestales, valga la reiteración- es lícito intercambiar las semillas, guardarlas y resembrarlas, vender "como materia prima o alimento el producto obtenido del cultivo de la variedad protegida", y esto porque el derecho del obtentor no va hasta el producto final o el elaborado o fabricado con base en el mismo, como sí ocurre en la versión upov de 1991.

La norma comunitaria andina tiene un efecto social muy positivo: resguardar la soberanía y seguridad alimentaria al no reconocerle al obtentor la prerrogativa de impedir la venta de la cosecha o practicar medidas cautelares sobre la misma, en los cultivos básicos para la satisfacción de las necesidades alimenticias de la población como el maíz, arroz, etc. La limitación a especies frutícolas, ornamentales o forestales es válida conforme al upov de 1978, y no es una "barbaridad" como

29. upov/78, artículo 2 numeral 2), que reza: "Cada Estado de la Unión podrá limitar la aplicación del presente Convenio, dentro de un género o de una especie, a las variedades que tengan un sistema particular de reproducción o de multiplicación o cierta utilización final". Disponible en [www.upov.int/export/sites/upov/upovlex/es/conventions/1978/ act1978.pdf], recuperado el 26 de marzo de 2016.

30. upov/91, artículo 14, numeral 2. Disponible en [www.upov.int/upovlex/es/conventions/1991/act1991.html], recuperado el 26 de marzo de 2016.

31. UPOV/91, artículo 14, numeral 3. 
sostienen sus críticos $^{32}$. Por el contrario, el artículo 26 de la Decisión 345 no suscitó controversia alguna durante muchos años.

La regla general consistente en que la reutilización que haga el agricultor o la venta como materia prima o alimento del producto final no constituye violación, se encuentra plenamente justificada cuando se trata de plantas que se reproducen por semilla; por el contrario, cuando la reproducción o multiplicación se hace por medio de esquejes o injertos, como sucede con las especies frutícolas o las plantas ornamentales, es necesario que la norma extienda la protección al producto final para no patrocinar una violación legal de los derechos del obtentor ${ }^{33}$.

\section{Convenio sobre diversidAd biolóGica y DeCisión 39I DE 1996}

El Convenio sobre Diversidad Biología (СDв) de 1992, aprobado mediante Ley 165 de 1994 y ratificado por más de 170 países, es reiterativo en la necesidad de "compartir equitativamente los beneficios que se deriven de la utilización de los conocimientos tradicionales" 34 . Entre sus objetivos, además de la conservación de la diversidad biológica y su "utilización sostenible", en forma expresa establece la necesaria "participación justa y equitativa en los beneficios que se deriven de la utilización de los recursos genéticos" 35 .

Para el análisis de los derechos de las comunidades campesinas, nativas o indígenas y afroamericanas, conviene destacar que el CDB consagra que cada Estado parte,

Con arreglo a su legislación nacional, respetará, preservará y mantendrá los conocimientos, las innovaciones y las prácticas de las comunidades indígenas y locales que entrañen estilos tradicionales de vida pertinentes para la conservación y la utilización sostenible de la diversidad biológica y promoverá su aplicación más amplia, con la aprobación y la participación de quienes posean esos conocimientos, innovaciones y prácticas, y fomentará que los beneficios derivados de la utilización de esos conocimientos, innovaciones y prácticas se compartan equitativamente ${ }^{36}$.

32. Cfr. Robledo del Castillo, Pablo Felipe. Director de la investigación. Los derechos del obtentor de variedades vegetales en Colombia, Bogotá, Universidad Externado de Colombia, 2006, p. 191. En el prólogo a esta obra, Ernesto Rengifo García, director del Departamento de Propiedad Intelectual de la Universidad Externado de Colombia, hace una importante precisión: "hay algunos puntos que no se comparten, sobre todo aquel referido a la interpretación que los autores le dan a la excepción del 'privilegio del agricultor', la cual estaría en contravía con una moderna postura que no ve con buenos ojos las restricciones que se le están imprimiendo hoy al ejercicio de la limitación y excepciones a los derechos de propiedad intelectual”. Ibíd., p. 14.

33. Pachón, Manuel y Sánchez Ávila, Zoraida. El régimen andino de la propiedad industrial, Bogotá, Ediciones Jurídicas Gustavo Ibáñez, 1995, p. 346.

34. СDв, Preámbulo, párr. 12. Disponible en [www.cbd.int/doc/legal/cbd-es.pdf], Recuperado el 26 de marzo de 2016.

35. Ibíd., artículo 1.

36. Ibíd., artículo 8, literal j). 
De manera que cuando se realiza un fitomejoramiento sobre una planta, especie o variedad silvestre o autóctona que existe gracias a que la comunidad indígena, afroamericana o raizal campesina la ha conservado y preservado evitando su extinción, los beneficios derivados de ese fitomejoramiento deben ser compartidos con dichas comunidades. Con mayor razón cuando sobre estas plantas exista un conocimiento ancestral o tradicional asociado, lo que se presenta en casi todos los casos.

El artículo $15 \mathrm{CDB}$, numeral 1, consagra "los derechos soberanos de los Estados sobre sus recursos naturales", y la discrecionalidad que tienen para regular el acceso a ellos. Dispone también la obligatoriedad de "compartir en forma justa y equitativa los resultados de las actividades de investigación y desarrollo y los beneficios derivados de la utilización comercial y de otra índole de los recursos genéticos" ${ }^{37}$.

La Decisión 391 de 1996, Régimen Común sobre Acceso a los Recursos Genéticos de la Comunidad Andina de Naciones, sigue lo preceptuado por el CDB y contiene una normatividad imperativa al respecto ${ }^{38}$. Es iterativa en la "participación justa y equitativa en los beneficios derivados del acceso" a que tienen derecho los pueblos indígenas, afroamericanos y comunidades raizales campesinas ${ }^{39}$.

Los recursos genéticos son "inalienables, imprescriptibles e inembargables" ${ }^{40}$, patrimonio soberano de cada uno de los países miembros de la CAN ${ }^{41}$. Las comunidades indígenas, afroamericanas y locales tienen "la facultad para decidir [...] sobre sus conocimientos, innovaciones y prácticas tradicionales asociados a los recursos genéticos y sus productos derivados" ${ }^{\$ 2}$.

Por ende, en el contrato de acceso a los recursos genéticos es obligatorio incorporar un anexo, que forma parte integrante del mismo, en el que se prevea "la distribución justa y equitativa de los beneficios provenientes de la utilización”³ del conocimiento tradicional asociado a los recursos genéticos.

\section{Protocolo de nagoya y Reglamento (Ue) N. ${ }^{\circ}$ 5il/2OI4}

El Protocolo de Nagoya de 2010, "sobre Acceso a los Recursos Genéticos y Participación Justa y Equitativa en los Beneficios que se Deriven de su Utilización al Convenio sobre la Diversidad Biológica", ratifica la protección que se debe brindar a los mismos, al igual que a los conocimientos tradicionales a ellos asociados. Reconoce la íntima relación existente entre los recursos genéticos y los conocimientos tradicionales ${ }^{44}$.

37. Ibíd., artículo 15, numeral 7.

38. Decisión 391 de 1996 de la Comunidad Andina de Naciones. Disponible en [www.minambiente.gov.co/images/BosquesBiodiversidadyServiciosEcosistemicos/pdf/Recursos_ Gen\%C3\%A9ticos_/Decisi\%C3\%B3n_391_de_1996.pdf], recuperado el 26 de marzo de 2016.

39. Ibíd., artículo 2, literal a).

40. Decisión 391 de 1996, artículo 6.

41. Ibíd., artículo 5.

42. Ibíd., artículo 7.

43. Ibíd., artículo 35 .

44. Protocolo de Nagoya, preámbulo, p. 3. Disponible en [www.cbd.int/abs/doc/protocol/ nagoya-protocol-es.pdf], recuperado el 26 de marzo de 2016. 
El Protocolo de Nagoya es reiterativo en que "las comunidades indígenas y locales" deben participar en una forma justa y equitativa en los beneficios derivados del acceso a los recursos genéticos que se encuentren en sus territorios, al igual que por sus conocimientos asociados a dichos recursos ${ }^{45}$, para lo que es indispensable el consentimiento fundamentado previo de dichas comunidades ${ }^{46}$.

Setenta y tres (73) países han ratificado el Protocolo de Nagoya ${ }^{47}$, por lo que ya se superó el número requerido, de cincuenta (50) países, para su entrada en vigencia $^{48}$. España, Guatemala, Guyana, Honduras, India, Indonesia, Kenia, México, Panamá, Perú, Sudáfrica, Unión Europea, Uruguay, figuran entre los países que lo han ratificado, y entre ellos no aparece Colombia.

\begin{abstract}
El Protocolo [...] proporciona una base sólida para una mayor certeza y transparencia jurídicas tanto para los proveedores como para los usuarios de recursos genéticos. Dos novedades importantes del Protocolo son una serie de obligaciones concretas que cada parte deberá asumir para asegurar el cumplimiento de la legislación o los requisitos reglamentarios nacionales de la Parte que proporciona los recursos genéticos, y la obligación de cumplir condiciones de cooperación mutuamente acordadas. Estas disposiciones relacionadas con el cumplimiento de leyes y requisitos junto con disposiciones que establecen unas condiciones más predecibles para el acceso a recursos genéticos contribuirán a asegurar la participación en los beneficios cuando dichos recursos salgan de la Parte que los proporciona. Asimismo, las disposiciones del Protocolo relativas al acceso a los conocimientos tradicionales de las comunidades indígenas y locales cuando dichos conocimientos están relacionados con recursos genéticos fortalecerán la capacidad de esas comunidades para beneficiarse del uso de sus conocimientos, innovaciones y prácticas ${ }^{49}$.
\end{abstract}

El Protocolo prevé establecer un "Centro de Intercambio de Información sobre Acceso y Participación en los Beneficios para el Acceso..." a los conocimientos tradicionales asociados con los recursos genéticos, con miras a informar de sus obligaciones a los posibles usuarios de estos recursos y conocimientos tradicionales; así como para asegurar la distribución equitativa de los beneficios derivados de su utilización que les corresponde a las comunidades indígenas y locales, contando siempre con su participación y anuencia ${ }^{50}$. Se deben establecer "puntos focales nacionales y autoridades nacionales competentes" encargadas de velar por la observancia de estas disposiciones y de informar a los solicitantes de acceso sobre

45. Ibíd., artículo 5, numerales 2 y 5.

46. Ibíd., artículos 6, numeral 2, y 7.

47. Organización Mundial de la Propiedad Intelectual (омpI), Protocolo de Nagoya, “Total Partes Contratantes: 73”. Disponible en [www.wipo.int/wipolex/es/other_treaties/parties. jsp?treaty_id=311\&group_id=22], recuperado el 26 de marzo de 2016.

48. Protocolo de Nagoya, artículo 33.

49. Secretaría del Convenio sobre la Diversidad Biológica, Protocolo de Nagoya sobre Acceso y Participación en los Beneficios..., "Introducción”, Montreal, 2011. Disponible en [www.cbd.int/abs/doc/protocol/nagoya-protocol-es.pdf], recuperado el 15 de abril de 2016. Bastardillas fuera de texto.

50. Protocolo de Nagoya, artículos 12 y 14 . 
la forma en que deben proceder ${ }^{51}$. El correspondiente permiso o autorización expedido por la autoridad nacional competente, comunicado al Centro de Intercambio de Información, "constituirá un certificado de cumplimiento reconocido internacionalmente" 52 . Este certificado será la prueba de que el acceso es legal, que se ha obtenido el consentimiento fundamentado previo y acordado la participación en los beneficios ${ }^{53}$.

El Reglamento (UE) n.o 511/2014 del Parlamento Europeo y del Consejo de 16 de abril de 2014, "relativo a las medidas de cumplimiento de los usuarios del Protocolo de Nagoya sobre el acceso a los recursos genéticos y participación justa y equitativa en los beneficios que se deriven de su utilización en la Unión" ${ }^{4}$, constituye un importante paso para su aplicación, si bien presenta algunos vacíos y deficiencias cuyo análisis excede el propósito del presente artículo. Empero, hay que destacar las precisiones en la exigencia del "certificado de conformidad reconocido a nivel internacional" 55 , y, a falta de este, la prueba de que se están acatando las disposiciones sobre acceso a los recursos genéticos y conocimientos tradicionales asociados ${ }^{56}$. De no haber procedido así, esto es, en el evento de que no se tenga el "certificado de conformidad" o la prueba de que se ha accedido al recurso genético en forma legal y pactado la participación justa y equitativa de la comunidad nativa o local, en retribución a su conocimiento tradicional, el resultado o producto final no podrá comercializarse o introducirse en el mercado de la Unión Europea. Esta es una importante disposición que apunta a frenar la biopiratería. No obstante, se pregunta: ¿por qué la exigencia no se hace también para adelantar el trámite de la patente? Parece incoherente la hipótesis de que al producto se le haya concedido la patente, pero que no se pueda comercializar por ausencia del "certificado de conformidad" o la prueba de que el acceso al recurso genético y conocimiento tradicional asociado ha sido legal ${ }^{17}$.

\section{E. Derechos de los pueblos indígenas}

El derecho de los pueblos indígenas merece un acápite especial por ser la culminación de un largo proceso para su promulgación. En una apretada síntesis, la Declaración de las Naciones Unidas sobre los Derechos de los Pueblos Indígenas ${ }^{58}$, aprobada el 13 de septiembre de 2007, consagra el derecho que les asiste a su "libre

51. Ibíd., artículo 13.

52. Ibíd., artículo 17, numeral 2.

53. Ibíd., artículo 17, numeral 3.

54. Disponible en [http://eur-lex.europa.eu/legal-content/Es/TXT/PDF/?uri=CELEX:32014R0511\&rid=1], recuperado el 15 de abril de 2016.

55. Ibíd., artículo 3, numeral 11).

56. Ibíd., artículo 4 .

57. Agradezco a Carlos Conde Gutiérrez, docente investigador del Departamento de Propiedad Intelectual de la Universidad Externado de Colombia, la muy atinada observación al respecto.

58. Declaración Universal de los Derechos de los Pueblos Indígenas. Disponible en [www.un.org/esa/socdev/unpfii/documents/Drips_es.pdf]. Recuperado el 26 de marzo de 2016. 
determinación" tanto en "su condición política" como en su "desarrollo económico, social y cultural" 59 . En consecuencia, "tienen derecho a la autonomía o al autogobierno en las cuestiones relacionadas con sus asuntos internos y locales" 60 . También a "participar en la adopción de decisiones en las cuestiones que afecten a sus derechos"61, y su consentimiento debe ser "libre, previo e informado"62.

Los pueblos indígenas tienen derecho a sus tierras, territorios y recursos que han poseído $o^{63}$, a preservar su patrimonio cultural y su conocimiento tradicional, los recursos "genéticos, las semillas, las medicinas, el conocimiento de las propiedades de la fauna y la flora" 64 . "También tienen derecho a mantener, controlar, proteger y desarrollar su propiedad intelectual de dicho patrimonio cultural, sus conocimientos tradicionales y sus expresiones culturales tradicionales" ${ }^{15}$.

Se consagra así, en este instrumento internacional, la Propiedad Intelectual Indígena, con mayúsculas, derechos intelectuales colectivos cuya titularidad está en cabeza de toda la comunidad, saber ancestral comunitario, que también puede ser especializado y calificado como el del chamán, con una característica que asombra a los "civilizados", y es la de que este no lo utiliza para su lucro personal sino que está al servicio de la comunidad, en virtud de una conjunción de valores sociales y espirituales. La Propiedad Intelectual Indígena no se encuentra en el dominio público por cuanto es patrimonio de la comunidad, que la preserva y acrecienta.

Tras reiterar el derecho que les asiste a la participación justa y equitativa en los beneficios, el consentimiento fundamentado previo como requisito sine qua non para acceder a los conocimientos tradicionales asociados a los recursos genéticos, un "mecanismo mundial multilateral de participación en los beneficios" "66 "certificados de cumplimiento reconocidos internacionalmente" ${ }^{67}$, etc., se aclara al final: "Nada de lo contenido en la presente Declaración [...] se entenderá en el sentido de que autoriza o alienta acción alguna encaminada a quebrantar o menoscabar, total o parcialmente, la integridad territorial o la unidad política de Estados soberanos e independientes" 68 .

Si bien una cosa es autonomía y otra es independencia, es muy diciente la remisión a las autoridades y la legislación nacionales, que parece ser una constante en este tipo de instrumentos internacionales; recuérdese la misma remisión que hace el TIRFAa después de enunciar los derechos de los agricultores ${ }^{69}$. En este punto, respecto del CDB y la normatividad que lo desarrolla, al igual que ocurre

59. Ibíd., artículo 3.

60. Ibíd., artículo 4.

61. Ibíd., artículo 18.

62. Ibíd., artículo 19.

63. Ibíd., artículo 26 ss.

64. Ibíd., artículo 31, numeral 1, se resalta.

65. Ibíd., artículo 31, numeral 1 , se resalta.

66. Ibíd., artículo 10.

67. Ibíd., artículo 17, literal a), párrafo iii).

68. Ibíd., artículo 46, numeral 1.

69. TIRFAA, artículo 9.3. 
con el derecho internacional de derechos humanos (DIDH), la regulación carece de dientes o no los tiene tan eficientes como en el caso del ADPIC (Acuerdo sobre los Aspectos de los Derechos de Propiedad Intelectual relacionados con el Comercio), además de que se estableció la patentabilidad de medicamentos o que “"importar es explotar"! ! ${ }^{70}$ También en los TLC se impuso la cláusula de anulación y menoscabo que sanciona la intervención del Estado en defensa del interés público, cuando quiera que se limite o disminuya la prospección de utilidad estimada por la compañía multinacional ${ }^{71}$.

La diferencia salta a la vista cuando se advierte la falta de una norma que a nivel global, como en el caso del ADPIC, exija el certificado de origen del recurso genético, la prueba del consentimiento fundamentado, libre y previo, de las comunidades étnicas, locales o campesinas, y la participación justa y equitativa de estas comunidades en los beneficios que se obtuvieren. Esta mínima documentación prevendría la biopiratería, y no se carece de dichas disposiciones porque no se haya planteado su oportunidad, sino otra vez por razones de geopolítica o por la conocida asimetría en las relaciones centro-periferia.

El Comité Intergubernamental sobre Propiedad Intelectual y Recursos Genéticos, Conocimientos Tradicionales y Folclore de la Organización Mundial de la Propiedad Intelectual (OMPI) ha discutido sobre el particular por más de diez años:

... divulgar la fuente generará confianza mutua en la relación Norte-Sur. Además, reforzará la complementariedad entre el sistema de acceso y participación en los beneficios y el sistema de [propiedad intelectual] [patentes].

[Las oficinas de [P.I.] [patentes] deben/deberán imponer un requisito obligatorio de divulgación ${ }^{72}$.

Que divulguen [el país de origen [y]] [o, de no conocerse éste,] la fuente de los recursos genéticos[, sus derivados] y los [conocimientos tradicionales conexos] [conocimientos tradicionales asociados a los recursos genéticos $]^{73}$.

\section{E. Biopiratería}

Los casos de biopiratería son aberrantes; baste citar algunos, para dimensionar el despojo. El fríjol "enola" fue patentado en Estados Unidos donde sí se permite

70. ADPIC, artículo 27.1. Decisión 486 de 2000, artículo 60 .

71. Cfr. César Rodríguez Garavito. "Lluvia de demandas", en El Espectador, 1 de abril de 2016, p. 23.

72. омpi, Comité Intergubernamental sobre Propiedad Intelectual y Recursos Genéticos... Documento consolidado en relación con la propiedad intelectual y los recursos genéticos, 19 de febrero de 2016. Disponible en [www.wipo.int/edocs/mdocs/tk/es/wipo_grtkf_ic_30/wipo_grtkf_ic_30_4.pdf]. pp. 5-6, recuperado el 15 de abril de 2016.

73. Ibíd., p. 8. Los corchetes y paréntesis indican la controversia al respecto, no acuerdo y discusión. 
el patentamiento de plantas, a diferencia de la normatividad de la Comunidad Andina de Naciones que lo prohíbe en forma expresa ${ }^{74}$. Esta variedad de fríjol, que en México es conocida como "mayocoba", fue desarrollada por campesinos de dicho país y fueron ellos sus verdaderos obtentores o creadores mediante técnicas de mejoramiento tradicional. Esta patente fue anulada después de un largo proceso en Estados Unidos, por no cumplir con el requisito de "no obviedad" que allí se exige.

Otro caso muy sonado fue con el yagé, ayahuasca o ayahuasa, planta utilizada por diferentes tribus del Amazonas en ritos sagrados, también patentada en Estados Unidos y cuya demanda de nulidad interpuesta por la Coordinadora de las Organizaciones Indígenas de la Cuenca Amazónica (COICA) prosperó, pero no por la depredación a estos pueblos sino porque la "nueva" variedad patentada... iya se encontraba descrita en el herbario de la Universidad de Michigan! ${ }^{15}$.

La evanta fue patentada por el Instituto Francés de Investigación Científica para el Desarrollo en Cooperación (оRSTOM), como un producto natural contra la leishmaniasis, pero se trata de una planta utilizada de tiempo atrás por la comunidad indígena chimane de la selva amazónica. La quinua, planta originaria del altiplano de Bolivia y cultivada también en Perú, Ecuador, Colombia, Chile y Argentina, era considerada por los Incas como un alimento sagrado y empleada para diferentes usos medicinales; sin embargo, fue patentada por agrónomos de la Colorado State University. En palabras de Monroy Rodríguez, "La patente recae sobre las plantas masculinas estériles de la variedad de quinua tradicional Boliviana 'Aplawa', sobre su uso para crear otras variedades híbridas de quinua e incluso abarca todas las plantas que se produzcan con este germoplasma. El interés de esta patente, es que permite el desarrollo de variedades híbridas, con las cuales se obtendrían cosechas más grandes" 76 .

La maca es originaria de la sierra central de los Andes de Perú, conocida también por los Incas y con múltiples propiedades medicinales: tratamiento para la infertilidad, frigidez, impotencia sexual, astenia, y tiene propiedades anticancerígenas; ha sido llamada "el viagra natural" y en consecuencia es codiciada por los biopiratas. Por su parte, el árbol del nim es utilizado en India, desde tiempos ancestrales, como antiparasitario, antiespasmódico, anticoagulante, alimento para el ganado, abono y antifungicida, por lo que se lo considera "un árbol milagroso". La transnacional W.R. Grace lo patentó para comercializar un producto a base de "aceite de neem". Hasta los arroces basmati y jazmín, variedades campesinas de India y Tailandia, fueron objeto de patentes, si bien, ante la evidencia de los hechos, tuvieron que ser revocadas.

74. Decisión 486 de 2000, artículo 20, literal c).

75. Cfr. Uribe Arbeláez. La transformación de la Propiedad Intelectual, cit., p. 262.

76. Monroy Rodríguez, Juan Carlos. Director de la investigación. Régimen de protección socio jurídica de los conocimientos tradicionales en Colombia, Bogotá, Universidad Externado de Colombia, 2006, p. 157. 
Para justificar la patente, lo primero que hacen es identificar el rasgo o característica específica de la variedad tradicional y hallar su genotipo. Luego lo cruzan mediante técnicas convencionales con otras variedades existentes. El resultado se rotula con una denominación distinta y se reclama la patente para la "nueva" planta. Todo un malabarismo biológico jurídico que envidiaría el más pícaro de los rábulas. Lo inaudito es que estos morteros de alquimistas funcionen a la manera de una nueva piedra filosofal, ya no para transformar los metales en oro sino las conocidas variedades vegetales en patentes ${ }^{77}$.

No sobra aclarar que también ha habido solicitudes de patentes denegadas por no cumplir con los requisitos de novedad y altura o actividad inventiva. Un ejemplo es ilustrativo. Los indígenas del Amazonas conocían el valor medicinal de la corteza de cinchona o chinchona para tratar la fiebre porque contiene quinina, aun cuando ellos no sabían de la existencia de este ingrediente activo. El hecho es que gracias a estas comunidades indígenas que conocían las propiedades asociadas a esta planta, los conquistadores y europeos se beneficiaron de sus propiedades terapéuticas. Al patentarse su síntesis química, ¡es equitativo que quienes posibilitaron el conocimiento de estas propiedades no perciban retribución alguna?

¿Los indígenas conocían la quinina? [...] Bajo la descripción de una cualidad de la corteza que la hace útil para tratar las fiebres, ellos obviamente la conocían [...] No importa que ellos escojan etiquetarla en términos de animismo o químicos. Ellos saben que la corteza tiene una cualidad que la hace buena para la fiebre y esa es una descripción de quinina $[\ldots]$

Esto demuestra que hay descripciones bajo las cuales se puede tener un conocimiento relevante sobre algo, aún sin saber su composición química o su estructura molecular. El hecho de que la sustancia sea natural o artificial no le quita validez a esta afirmación ${ }^{78}$.

Por lo mismo, el conocimiento tradicional asociado a un recurso genético debe ser recompensado, y así se consagra en los instrumentos internacionales reseñados. No reconocer su aporte o valor es una de las modalidades de la biopiratería.

\section{ADPIC ARTÍ́CULO 27.3 LITERAL B}

El ADPIC ${ }^{79}$ exige proteger las obtenciones vegetales bien sea por medio de patentes, un "sistema eficaz sui generis" o una combinación de ambos. Este artículo fue

77. Uribe Arbeláez. La transformación de la Propiedad Intelectual, cit., p. 264.

78. Cámara de los Lores, revisión del proceso, apelación, Merrell Dow Pharmaceuticals y otros, contra H.N. Norton \& Co. Limited. Open Law, Jisc BaIliI, párrafos 37 y 39. Disponible en [www.bailii.org/uk/cases/ukhl/1995/14.html], recuperado el 16 de abril de 2016. Traducción libre.

79. ADPIC. Disponible en [www.wto.org/spanish/docs_s/legal_s/27-trips.pdf], recuperado el 26 de marzo de 2016. 
bastante discutido porque conllevaba la patentabilidad de materia viva, pero en lo relacionado con las nuevas variedades vegetales abría la puerta a un sistema sui generis, lo que en principio parecía bastante flexible.

Muchos países en desarrollo para la época del Acuerdo de Marrakech en 1994, que dio origen a la OMC y su Anexo 1C, el del famoso ADPIC, que entraría a regir en 1995, hacían parte del Convenio upov (Unión para la Protección de los Obtentores de Variedades Vegetales) en su versión de 1978, que ofrecía gran discrecionalidad a los Estados en tanto que permitía una adecuación a los respectivos intereses nacionales. Por ello, se entendió que el Acta de 1978 del Convenio upov era el sistema sui generis al que remitía el artículo 27.3 literal b) del ADPIC y que este era el modelo a seguir. El problema surgió cuando en los "acuerdos de promoción comercial" o tratados bilaterales de libre comercio, TLC, se obligó a que los países que los celebraban, seducidos por el espejismo del "libre comercio" ${ }^{80}$, adoptaran la versión upov de 1991 que extendía el contenido de los derechos del obtentor más allá de lo que estaba previsto.

El artículo 16.1 del "Acuerdo de Promoción Comercial" Colombia-Estados Unidos, Ley 1143 de 2007, en su numeral 3 y literal c) dice:

3. Cada parte ratificará o adherirá a los siguientes acuerdos hasta el 1 de enero de 2008, o a la entrada en vigor de este Acuerdo, cualquiera que sea posterior:

[...] c) el Convenio Internacional para la Protección de las Obtenciones Vegetales (Convenio upov) $(1991)^{81}$.

Otro gran problema es que el artículo 27.3 literal b) ADPIC es una rueda suelta dentro del andamiaje institucional de otros tratados internacionales de igual o superior jerarquía. No tuvo en cuenta lo dispuesto en el CDB de 1992, y tampoco está acorde con el Tratado Internacional sobre los Recursos Fitogenéticos para la Alimentación y la Agricultura de 2001, para citar sólo los más relevantes. Desconoce así el importante papel que han desempeñado las comunidades indígenas, afroamericanas y raizales campesinas en la conservación de la biodiversidad, el derecho que tienen a participar en los beneficios derivados del acceso a los recursos genéticos por ellos preservados, la soberanía de los Estados sobre dichos recursos, los derechos de los agricultores y comunidades campesinas a conservar, limpiar, guardar o almacenar semillas, resembrarlas, intercambiarlas y venderlas en el mercado local como se ha hecho desde tiempos inmemoriales con plena conciencia de su licitud. Este derecho consuetudinario campesino es ignorado en el ADPIC no obstante que es reconocido por el TIRFAA.

80. Cfr. Martín Uribe Arbeláez. “Los 'beneficios' del trc”, Revista La Propiedad Inmaterial n..$^{\circ}$ 10-11, Universidad Externado de Colombia, 2007. Disponible en [http://revistas. uexternado.edu.co/index.php/propin/article/view/899/853]. Recuperado el 26 de marzo de 2016.

81. Disponible en [www.tlc.gov.co/publicaciones.php?id=727], recuperado el 26 de marzo de 2016. 
Por lo mismo, en el seno del Consejo de los ADPIC se ha debatido la reforma del artículo 27.3 literal b) ADPIC para hacerlo compatible con el CDB y el TIRFAA, con los que choca o está en contravía.

... los Miembros deberían confirmar el entendimiento común de que, con independencia del tipo de sistema sui generis que se adopte para proteger las obtenciones vegetales, los usos no comerciales de éstas y el empleo del sistema de ahorro de semillas e intercambio y venta entre los agricultores constituyen derechos y excepciones que deberían garantizarse como cuestiones importantes de política pública con objeto, entre otras cosas, de velar por la seguridad alimentaria y preservar la integridad de las comunidades rurales o locales [...] [E]n el párrafo 3 b) del artículo 27 debería intercalarse, después de la oración referente a la protección de la obtenciones vegetales, una nota a pie de página en la que se afirmara que toda legislación sui generis sobre protección de las obtenciones vegetales puede establecer: i) la protección de las innovaciones de comunidades agrarias autóctonas y locales en los países en desarrollo, en consonancia con el Convenio sobre la Diversidad Biológica y el Compromiso Internacional sobre Recursos Fitogenéticos; ii) la continuidad de las prácticas tradicionales de explotación agraria, incluido el derecho a intercambiar y guardar semillas y a vender la producción de los agricultores; y iii) la prevención de derechos o prácticas anticompetitivos que amenacen la soberanía alimentaria de la población de los países en desarrollo [...] y que amparen, como mínimo, los derechos de los agricultores, en particular a sembrar e intercambiar las semillas cosechadas de una variedad protegida, los derechos de las comunidades y la concesión de licencias obligatorias cuando las obtenciones vegetales no estén disponibles en condiciones comerciales razonables ${ }^{82}$.

\section{UPOV I99I}

El Convenio upov fue concebido como una protección especial para estimular el fitomejoramiento de plantas, que no encajaba en el régimen de patentes por ser demasiado estricto. Se trata de un sistema sui generis, especial, que a grandes rasgos se caracteriza por la particularidad del objeto de protección: nuevas variedades vegetales, materia viva, que puede reproducirse y, por ende, la multiplicación o propagación está comprendida dentro de esta protección. El concepto de novedad es diferente del tradicional derecho de patentes y se consideraba que tiene un mayor margen de flexibilidad. En su visión primigenia se propendía por el estímulo al fitomejoramiento, pues era lícito tomar una variedad registrada, mejorarla y a

82. Organización Mundial del Comercio - Consejo de los Aspectos de los Derechos de Propiedad Intelectual relacionados con el Comercio. "Examen de las disposiciones del párrafo 3 b) del artículo 27 - Resumen de las cuestiones planteadas y las observaciones formuladas", IP/C/W/369/Rev.1, 9 de marzode 2006, pp. 19-20. Disponible en [www. wto.org/spanish/tratop_s/trips_s/ipcw369r1.doc], recuperado el 26 de marzo de 2016. 
su vez solicitar una nueva protección ${ }^{83}$. Otra singularidad es que la duración del tiempo de protección no es estándar y varía según el tipo de variedad.

La primera revisión sustantiva del Convenio upov de 1961 se efectuó el 23 de octubre de 1978 y se conoce como Acta de 1978, a la que se adhirieron la mayor parte de los países latinoamericanos ${ }^{84}$. Lo que se explica por la mayor flexibilidad que confiere el Acta de 1978, como ya se señaló.

Con el auge de la biotecnología se planteó la revisión del Acta de 1978, con miras a integrar en el sistema Upov a los países que, como Estados Unidos, tenían una protección mediante patentes, fortaleciendo las prerrogativas del obtentor y haciendo obligatorio el régimen para todas las variedades vegetales.

La propuesta de modificación de UPOV 1978 fue impulsada por la Federación Internacional de Semillas cuyos miembros asociados son Bayer SAS, BayerCropScience, Nestlé R\&D Center Plant Science \& Technology, Monsanto Holland BV, Monsanto International Sarl, Syngenta Crop Protection AG, Dupont Pioneer y Dow AgroSciences LLC, filial de The Dow Chemical Company ${ }^{85}$, entre otros.

No cabe duda de que la versión de 1991 del Convenio upov tiene por finalidad reforzar los derechos del obtentor, pero para una mejor comprensión hay que repasar conceptos básicos. Una variedad vegetal mejorada debe cumplir con los requisitos de novedad, distintividad, homogeneidad y estabilidad, para ser protegida. El concepto de novedad es diferente al tradicional del derecho de patentes que se refiere a la comparación con el estado de la técnica ${ }^{86}$; en el régimen de variedades vegetales la novedad no es técnica sino comercial, previa divulgación antes de la presentación de la solicitud de registro dentro de unos plazos que varían según la especie de que se trate.

La comercialización no puede ser superior a un (1) año antes de la fecha de solicitud de registro en el respectivo país, y en otro Estado miembro de la upov por un periodo mayor a cuatro (4) años siempre y cuando no se trate de "vides, árboles forestales, árboles frutales y árboles ornamentales, con inclusión, en cada caso, de sus portainjertos" ${ }^{\prime 7}$ : especies para las cuales existe un plazo mayor, que en todo caso no puede ser superior a seis (6) años ${ }^{88}$. La versión UPOv de 1991 precisa que la comercialización previa debe haber recaído sobre "el material de reproducción o de multiplicación vegetativa” ${ }^{89}$, con una adición muy importante cual es:

83. upov 1961, artículo 6, numeral 1), literal a). Disponible en [www.upov.int/en/publications/ conventions/1961/act1961.htm], upov 1978, artículo 6 numeral 1), literal a). Disponible en [www.upov. int/export/sites/upov/upovlex/es/conventions/1978/act1978.pdf], recuperado el 27 de marzo de 2016.

84. upov. "Miembros de la Unión Internacional para la Protección de las Obtenciones Vegetales... Situación al 22 de octubre de 2015”. Disponible en [www.upov.int/export/sites/ upov/members/es/pdf/pub423.pdf]. Recuperado el 27 de marzo de 2016.

85. International Seed Federation, associated members. Disponible en [www.worldseed. org/isf/associate.html], recuperado el 27 de marzo de 2016.

86. Decisión 486 de 2000, artículos 14 y 16. ADPIC, artículo 27.1 .

87. upov 1978, artículo 6, numeral 1), literal b) ii).

88. upov 1978, artículo 6, numeral 1), literal b).

89. upov 1991, artículo 6, numeral 1). Disponible en [www.upov.int/upovlex/es/conventions/1991/act1991.html\#P360_22348], recuperado el 28 de marzo de 2016. 
"o un producto de cosecha de la variedad" esta versión de 1991 se extienden hasta el producto de la cosecha, lo que antes no se contemplaba por ser una prerrogativa extrema. También suprime la expresión "ofrecida en venta" ${ }^{11}$ que traía la versión de 1978, cambiándola por "vendido o entregado a terceros de otra manera" ${ }^{2}$, lo que es distinto porque una cosa es ofrecer en venta y otra vender en forma efectiva, con lo que el requisito de novedad, entendido como ausencia de previa comercialización, se restringe, para ampliar las posibilidades de que el obtentor no la pierda sino sólo en el caso de mercadeo o venta cierta de su variedad.

La distintividad hace relación a las características especiales y singulares que debe tener la nueva variedad, "por uno o varios caracteres importantes", frente a las ya "notoriamente" conocidas ${ }^{93}$. La versión de 1991 eliminó la exigencia de que las diferencias en los caracteres fueran importantes, permitiendo así que una variación de menor entidad pueda ser protegid $a^{94}$.

El requisito de que sea homogénea ${ }^{95}$ quiere decir que la variedad debe ser uniforme, conservando sus "caracteres pertinentes" ${ }^{196}$ o "esenciales" ${ }^{\prime 97}$ en los sucesivos ciclos de reproducción sexuada o multiplicación vegetativa, tolerándose un margen mínimo de variabilidad. La estabilidad subraya el hecho de que tales caracteres esenciales se conserven de generación en generación ${ }^{98}$.

En cuanto al término "obtentor", el Acta de 1978 no lo definía. La Decisión 345 de 1993 en su artículo 4 prescribe que se "otorgarán certificados de obtentor a las personas que hayan creado variedades vegetales", y aclara: "entiéndase por crear, la obtención de una nueva variedad mediante la aplicación de conocimientos científicos al mejoramiento heredable de las plantas" ${ }^{\prime 9}$. La versión upov de 1991, artículo 1, dispone: “iv) se entenderá por 'obtentor' la persona que haya creado $o$ descubierto y puesto a punto una variedad"100. En consecuencia, ya no sería solo el "diseño" de una nueva variedad vegetal, "creación", lo que daría lugar, previo el lleno de los requisitos analizados, al derecho del obtentor, sino también "descubrir" una variedad preexistente o mutación natural de la misma y "ponerla a punto", hacerla apta para su multiplicación, siempre que pase el examen de novedad, distintividad, homogeneidad y estabilidad. Se ha rebajado así el "nivel inventivo", utilizando por

90. Ibíd. Cfr. unov/Exn/Nov Draft 3, "Notas explicativas sobre la novedad con arreglo al Convenio de la upov", p. 6. Disponible en [www.upov.int/edocs/mdocs/upov/es/c/43/ upov_exn_nov_draft_3.pdf], recuperado el 28 de marzo de 2016.

91. UPOV 1978, artículo 6, numeral 1), literal b).

92. upov 1991, artículo 6, numeral 1).

93. upov 1978, artículo 6, numeral 1), literal a).

94. upov 1991, artículo 7.

95. upov 1978, artículo 6, numeral 1), literal c).

96. upov 1991, artículo 8.

97. Decisión 345 de 1993, artículo 11 .

98. upov 1978, artículo 6, numeral 1), literal d). upov 1991, artículo 9. Decisión 345/93, artículo 12 .

99. Cursiva fuera de texto.

100. Cursiva fuera de texto. 
analogía y para mayor claridad la terminología requerida en el derecho de patentes. En otras palabras, de la versión upov de 1978, que exigía "crear", se ha pasado en la versión de 1991 a la aceptación de "descubrir y poner a punto", dándole vía libre a cualquier modificación de muchísima menor entidad para que de allí surja el derecho del obtentor, y por eso fue que también se eliminó el requisito de que las características de la nueva variedad presentaran diferencias "importantes" con las precedentes, que exigía el Acta de $1978^{[101]}$.

Desde el punto de vista de los países ricos en biodiversidad, como Colombia y Perú, el problema es que variedades silvestres o que perviven por la acción paciente de las comunidades ancestrales o campesinas pueden ser objeto de apropiación con el solo hecho de que se haga una mejora en cualquiera de sus características, no siempre relevante. Como ha dicho Lapeña, "en relación con las especies propagadas vegetativamente $[\ldots]$ la labor de "poner a punto" una variedad es relativamente sencilla, especialmente para las plantas ornamentales (ej. orquídeas) donde el proceso es mínimo. Por ejemplo, con un mínimo aporte técnico, el obtentor podría reclamar su derecho sobre cualquier orquídea extraída de la Amazonía peruana”102.

Puntualizando, a diferencia del Acta de 1978, la versión de 1991:

$1 .^{\circ}$ Extiende la protección a todos los géneros y especies ${ }^{103}$, en tanto que el Acta de 1978 exigía un máximo de 24 géneros o especies protegidas ${ }^{104}$, pero no todas.

2..$^{\circ}$ Extiende de los derechos del obtentor, que en el Acta de 1978 comprende: "la producción con fines comerciales, la puesta a la venta, la comercialización del material de reproducción o de multiplicación vegetativa, en su calidad de tal" y tratándose de plantas ornamentales este derecho comprende también las partes de cada una de estas que a su vez puedan reproducirse, esquejes o tallos ${ }^{105}$. La versión de 1991, amplía el listado de derechos: exportación, importación, posesión con fines de reproducción, ipudiéndose extender hasta el producto de la cosecha y a los fabricados directamente a partir de un producto de cosecha de la variedad protegida! ${ }^{106}$.

$3 .^{\circ}$ Cercena el derecho de paisanaje de reservar semilla, guardarla para utilizarla y resembrarla en una nueva cosecha, intercambiarla con sus vecinos e incluso venderla en el mercado local. Esta costumbre ancestral de las comunidades campesinas en todo el mundo es reconocida como derecho de paisanaje y constituye el núcleo del llamado "privilegio del agricultor" o excepción en favor del agricultor, entendiendo por tal no al agro-empresario sino al campesino o pequeño agricultor. "La referencia a la posesión, también supone un medio para hacer más efectivo

101. upov 1978, artículo 6, numeral 1), literal a).

102. Isabel Lapeña. "La propiedad intelectual sobre las semillas y sus implicaciones para la agricultura familiar en el Perú”, Serie de Política y Derecho Ambiental, n.o 25 , octubre de 2012, Lima, p. 5. Disponible en [http://orgprints.org/25051/7/25051.pdf]. Recuperado el 28 de marzo de 2016.

103. UPOV 1991, artículo 3, numeral 1), literal ii).

104. upov 1978, artículo 4, numeral 3), literal b), iii).

105. Upov 1978, artículo 5, numeral 1).

106. upov 1991, artículo 14. 
el derecho del obtentor ya que éste puede iniciar una acción, por ejemplo, por el mero almacenamiento de semilla sin esperar a que se produzca una venta u otro acto de comercialización expreso" 107 .

4. ${ }^{\circ}$ Modifica el principio de agotamiento del derecho previsto en el ADPIC ${ }^{108}$, impidiendo las importaciones paralelas, no obstante su proceder legitimo al haber sido introducida la nueva variedad vegetal por parte del titular del derecho en el mercado internacional, y monopolizando la importación de la variedad vegetal en el mercado nacional. ${ }^{109}$ Las importaciones paralelas son licitas en el derecho de patentes pero no en el régimen de obtentor, según la versión de 1991, cuyos derechos le otorgan el monopolio de importación.

... algunos países en desarrollo sostuvieron que si bien es cierto que ha aumentado el número de Estados miembros de upov 1991, un número importante de países en desarrollo se resiste a suscribirlo para preservar la flexibilidad de Upov 1978. En este sentido se destacó que upov 1978 permite a los agricultores almacenar, intercambiar y en cierta medida vender semillas de variedades protegidas, mientras que Upov 1991 transforma estos derechos en privilegios y excepciones, cuyo ejercicio dependerá de la discreción de los gobiernos que sólo podrán permitir el uso de las semillas por el agricultor en sus propias plantaciones, sujeto a "restricciones razonables" y teniendo en cuenta los "legítimos intereses" del obtentor. upov 1991 sólo permite el uso de las semillas en la misma plantación. Esto afectaría la seguridad alimenticia de muchas comunidades en países en desarrollo que dependen del almacenamiento, compartimiento y recultivo de semillas de anteriores cosechas (Kenya). La perspectiva de tener ahora que abonar regalías para llevar a cabo esas actividades afecta a los pequeños productores (Brasil). Además se sostuvo que UPOV 1991 sólo limita el derecho a vender o comercializar la semilla de la variedad protegida en el territorio de la parte contratante, lo que constituye una alteración del balance establecido por el artículo 6 del ADPIC, que permite a los Estados elegir el sistema de agotamiento de derechos que prefieran (Brasil) ${ }^{110}$.

5. ${ }^{\circ}$ Extiende el tiempo de duración de la exclusividad al pasar de diez y ocho (18) años para los árboles forestales, frutales, ornamentales y vides, incluyendo sus

107. Gianni, Carmen. "El derecho del obtentor en relación a la producción de material de reproducción o de multiplicación en los convenios de la upov. Limitaciones y excepciones al derecho de obtentor", en Distintas facetas de las variedades vegetales. Propiedad Intelectual, biotecnología agropecuaria, recursos genéticos, comercio de semillas, $\mathrm{t}$. I: "La Propiedad Intelectual de las variedades vegetales. El derecho de obtentor", Buenos Aires, Instituto Nacional de Semillas, Ministerio de Agricultura, Ganadería y Pesca, 2010, p. 87. Disponible en [www.inase.gov.ar/index.php?option $=$ com_remository\&Itemid $=102 \&$ func $=$ star tdown\&id=795], recuperado el 28 de marzo de 2016.

108. ADPIC, artículo 6.

109. UPOV 1991, artículos 14, numeral 1) vi), y 16.

110. Moncayo von Hase, Andrés. "La flexibilidad del adpic y su eventual erosión en las negociaciones bilaterales, multilaterales y regionales", en Generación y protección del conocimiento: propiedad intelectual, innovación y desarrollo económico, Martínez Piva, Jorge Mario (coord.), México, Cepal, 2008, p. 111. Disponible en [http://repositorio.cepal. org/handle/11362/2876], recuperado el 28 de marzo de 2016. Cursiva fuera de texto. 
portainjertos, a veinticinco (25), y para las otras plantas se eleva de quince (15) a veinte (20) años ${ }^{111}$.

6. Incluye la "excepción facultativa"112, en un texto bastante alambicado, siendo repetitiva y enfática en que primero que todo hay que proteger "los intereses legítimos del obtentor". De manera excepcional permite que los agricultores empleen el producto de la cosecha, léase semillas, "en su propia explotación", esto es para volver a sembrarlas pero "dentro de límites razonables y a reserva de la salvaguardia de los intereses legítimos del obtentor”. Toda una ambigüedad que pone en entredicho el derecho del agricultor para resembrar, costumbre ancestral, condicionándolo con una serie de cortapisas para en últimas, mutilarlo. El Acta de 1978 no decía nada sobre el privilegio del agricultor por la sencilla y evidente razón de que el ámbito de los derechos del obtentor que preveía no se extendían al "producto de la cosecha" y a "productos fabricados" a partir de ella, como sí lo hace la versión de $1991^{[113]}$.

De otra parte, hay que precisar que la Decisión 345 de 1993, a pesar de seguir en parte la versión UPOV de 1991, como en lo referente a las variedades esencialmente derivadas ${ }^{114}$ y la enunciación de derechos ${ }^{115}$, sin llegar al exceso de extenderlos a "productos fabricados" con base en la cosecha, presenta una diferencia fundamental: el ámbito de protección y la excepción o privilegio del agricultor, contemplados en forma mucho más amplia que la prevista en upov 1991. Mientras en la versión de 1991 la protección se debe extender a todos los géneros o especies vegetales, la Decisión 345, haciendo uso de la discrecionalidad que les confiere a los Estados el Acta de 1978, limita los derechos de obtentor a unas específicas y determinadas especies o géneros conforme a lo previsto en dicha Acta ${ }^{116}$. Esta es la razón de ser y la justificación del artículo 26 de la Decisión 345 que no restringe el derecho de paisanaje, esto es, guardar semillas para resembrarlas e intercambiarlas a título gratuito u oneroso, y por supuesto vender "como materia prima o alimento" la cosecha.

\section{Sin Obligación Legal, El ICA APLICA LA VeRsión UpOV DE I99I}

No obstante que la Corte Constitucional de Colombia declaró la inexequibilidad de la Ley 1518 de $2012^{[117]}$, aprobatoria de la incorporación del país al Convenio upov de 1991, por haber pretermitido la obligatoria consulta con las comunidades indígenas, afroamericanas y raizales campesinas, el ICA ha venido implementado de tiempo atrás el upov de 1991. La Resolución 970 de 2010 del ICA provocó la

111. upov 1978, artículo 8. upov 1991, artículo 19, numeral 2).

112. UPOV 1991, artículo 15, numeral 2).

113. UPOV 1991, artículo 14, numerales 2) y 3).

114. Decisión 345 de 1993, artículos 3, penúltimo párrafo, 24, inciso final, y 25, literal c).

115. Decisión 345 de 1993, artículo 24.

116. UPOV 1978, artículo 2, numeral 2.

117. Sentencia C-1051 de 2012, M.P.: Luis Guillermo Guerrero Pérez, disponible en [www.corteconstitucional.gov.co/relatoria/2012/C-1051-12.htm]. Recuperado el 28 de marzo de 2016. 
reacción en su contra y su aplicación fue suspendida en desarrollo de los acuerdos para levantar el paro nacional agrario de $2013^{[118]}$. En buena hora el ICA derogó dicha disposición, mediante Resolución 3168 de 7 de septiembre de 2015 ${ }^{[119]}$, vigente en la actualidad, que modera los desaciertos y excesos de aquella, tales como sancionar la simple tenencia de "semilla no identificada", "demostrar que ha habido agotamiento del derecho de obtentor" o la estigmatización implícita en el esperpento de "semilla legal" 120.

La Resolución 3168 de 2015 trae una disposición que, no exigiendo los absurdos de la 970 de 2010, como que el predio vecino esté a una distancia de más de mil metros y otros dislates como la prohibición de intercambiar semilla a título gratuito, continúa de todas formas en la línea de restringir el privilegio del agricultor:

Artículo 22. Privilegio del agricultor. El agricultor interesado en una variedad protegida por derecho de obtentor, tal como lo contempla la Decisión CAN 345 de 1993, podrá reservar producto de su propia cosecha para usarla como semilla para sembrarla en su misma explotación de conformidad con las áreas por especie así: Arroz hasta 5 has (una tonelada), soya hasta: 10 has ( 800 kilos), algodón hasta 5 has (60 kilos). Lo anterior sin perjuicio de lo establecido en las normas vigentes para los planes de manejo y bioseguridad.

No se entiende el porqué de la insistencia en anticipar la vigencia de la versión upov de 1991, sin existir obligación legal alguna de acatarla. Colombia no ha adherido a UPOV 91 y lo que es vinculante es el Acta de 1978 que por ninguna parte limita el privilegio del agricultor, como ya se ha explicado. Tampoco es comprensible la interpretación inversa que se hace del artículo 26 de la Decisión 345 de 1993. La exégesis literal de esta norma es muy clara en el sentido de que la regla general es el derecho a reservar y sembrar "para su propio uso", sin limitación de área o producción alguna, como también es lícito vender "como materia prima o alimento el producto obtenido de la variedad protegida”. Aquí no hay lesión al derecho del obtentor, que no se puede imponer contra el ancestral derecho de paisanaje de intercambiar o vender semillas en el mercado local, ni contra la atávica costumbre campesina de guardar, conservar, almacenar, seleccionar semilla y resembrarla. La excepción es cuando se trata de "especies frutícolas, ornamentales y forestales". Es la única excepción prevista en el artículo 26 de la Decisión 345 de 1993, vigente y de obligatorio cumplimiento para el país en tanto que es miembro de la CAN. Como norma comunitaria andina

118. Santos, María Teresa; García, Lisa et al. "Labriegos y defensores de semillas, indignados por decisiones del ICA", en El Tiempo, 30 de noviembre de 2013. Disponible en [www.eltiempo.com/archivo/documento/CMS-13236396], recuperado el 28 de marzo de 2016.

119. Resolución ICA 3168 de 2015, artículo 28, disponible en [www.ica.gov.co/ getattachment/4e8c3698-8fcb-4e42-80e7-a6c7acde9bf8/2015R3168.aspx], recuperado el 28 de marzo de 2016.

120. Resolución ICA 970 de 2010, artículos 12, 2.9.4, y 15, parágrafos 1 y 2, entre otros. Disponible en [www.fedearroz.com.co/documentos/2010/res_970.pdf], recuperado el 28 de marzo de 2016. 
es de aplicación preferente, prevalente y preeminente sobre la normatividad interna, que, por tanto, si le es contraria queda suspendida por aquella ${ }^{121}$.

El Acta de 1978 no extiende los derechos del obtentor al producto de la cosecha o al fabricado con base en ella ${ }^{122}$, todo lo contrario de lo que sucede en la versión uPOV de 1991 que sí lo establece, en contravía de los derechos de los agricultores $^{123}$. Esta es la ratio iuris del artículo 26 de la Decisión 345 de 1993, que sigue lo dispuesto en el Acta de 1978 en este aspecto fundamental para la agricultura campesina. Por lo mismo, se ha dicho y repetido que la versión upov de 1991 no es conveniente para el interés nacional. Lo insólito es que el ICA afirme lo contrario y a rajatabla se empeñe en anticipar la vigencia de upov 1991. La resolución en comento es una prueba de ello que en esto mantiene la trayectoria definida por el ICA desde las resoluciones de 2003.

La diferencia con lo que en este punto dispuso la Unión Europea, adherente a la versión upov de 1991, es abismal. Por una parte autoriza a sus agricultores para que re-siembren ${ }^{124}$, reconociendo esta costumbre ancestral, así esté vigente la exclusividad del obtentor. La norma comunitaria europea, a renglón seguido, enumera toda una serie de especies a las cuales se aplica dicha excepción: forrajeras, cereales, patatas, oleaginosas y textiles ${ }^{125}$. Precisando que "no habrá restricciones cuantitativas en la explotación del agricultor cuando así lo requieran las necesidades de la explotación", y que los pequeños agricultores no tendrán que pagar remuneraciones al titular de los derechos de obtentor ${ }^{126}$.

"Pequeño agricultor" en la Unión Europea es aquel que no cultive plantas "en una superficie superior a la que sería necesaria para producir 92 toneladas de cereales" ${ }^{27}$. Bastante diferente a la forma como se reglamentó en Colombia, incluso en cuanto a la extensión de la excepción que solo la autoriza para el caso del arroz "hasta 5 has (una tonelada)"128. ¿¿Será que el campesino colombiano tiene más dinero para pagar royalities que el europeo?

\section{V. “Ley de PRotección de las VARIEDAdes de plantas Y LOS DERECHOS DE LOS AGRICULTORES" DE INDIA (2OOI)}

La citada ley es un verdadero modelo para el mundo en desarrollo, y prueba que con entereza y voluntad política es posible salvaguardar la economía campesina,

121. Cfr. Tribunal de Justicia de la Comunidad Andina. Proceso 114-AI- 2004. Disponible en [intranet.comunidadandina.org/Documentos/Procesos/114-AI-2004.doc], recuperado el 29 de marzo de 2016.

122. upov 1978, artículo 5.

123. upov 1991, artículo 14 , numerales 2 y 3.

124. Reglamento (CE) n. ${ }^{\circ} 2100 / 94$, artículo 14, numeral 1. Disponible en [www.cpvo. europa.eu/documents/lex/consolidated/ES2100consolide.pdf], recuperado el 29 de marzo de 2016.

125. Ibíd., artículo 14, numeral 2.

126. Ibíd., artículo 14, numeral 3.

127. Ibíd.

128. Resolución ICA 3168 de 2015, artículo 22. 
respetando su derecho consuetudinario de reservar, intercambiar y vender semillas, al igual que reconocer su ancestral y paciente labor de fitomejoramiento. Está conforme con el ADPIC, artículo 27.3 literal b), que exige otorgar una protección efectiva a las obtenciones vegetales, y el sistema sui generis de India así lo hace ${ }^{129}$, equilibrando los derechos de los obtentores con los de los agricultores y comunidades campesinas, nativas o tribales, consagrados en el CDB y el TIRFAA, que son pretermitidos en el ADPIC y el Convenio uPOV ${ }^{130}$.

En India, la Autoridad de Protección de Variedades de Plantas y Derechos de los Agricultores ${ }^{131}$ está integrada de forma amplia tanto por los representantes de diferentes sectores gubernamentales relacionados con la materia, como por representantes de comunidades nativas, de los agricultores, la industria semillera, universidades y organizaciones de mujeres vinculadas al sector agrícola.

En una breve síntesis, se destacan los puntos siguientes.

\section{Nuevas definiciones de obtentor y variedades de los agricultores}

La sección 2 literal c) de la precitada ley consagra una definición de "obtentor o fitomejorador" diferente a la prevista en el Convenio upov de $1991^{[132]}$, al entender como tal a la persona o grupo de personas, agricultor o grupo de agricultores o una institución que ha creado, evolucionado o desarrollado una variedad.

(k) "farmers" means any person who-

(i) cultivates crops by cultivating the land himself; or

(ii) cultivates crops by directly supervising the cultivation or land through any other person; or

(iii) conserves and preserves, severally or jointly, with any other person any wild species or traditional varieties or adds value to such wild species or traditional varieties through selection and identification of their useful properties;

Por "agricultor" se entiende el que tradicionalmente cultiva y cosecha la tierra por sí mismo, o bajo su supervisión directa o indirecta, o a quien conserve y preserve en forma rigurosa y conjuntamente con cualquier otra persona especies silvestres o

129. India no forma parte del Convenio upov. Cfr. sitio web oficial, "Miembros de la Unión Internacional para la Protección de las Obtenciones Vegetales... Situación al 22 de octubre de 2015". Disponible en [www.upov.int/export/sites/upov/members/es/pdf/pub423. pdf], recuperado el 29 de marzo de 2016.

130. The Protection of Plant Varieties and Farmers' Rights Act, 2001. Disponible en [http://plantauthority.gov.in/pdf/pPV\&FRAct2001.pdf], recuperado el 29 de marzo de 2016. Traducción libre.

131. Sitio web [http://plantauthority.gov.in/index.htm], recuperado el 29 de marzo de 2016.

132. upov 91, artículo 1, numeral iv). 
variedades tradicionales, o les agregue valor a tales especies o variedades, mediante la selección e identificación de sus propiedades útiles ${ }^{133}$.

(l) "farmers' variety" means a variety which-

(i) has been traditionally cultivated and evolved by the farmers in their fields; or

(ii) is a wild relative or land race or a variety about which the farmers possess the common knowledge;

"Variedad de los agricultores" significa cualquier variedad que:

i) haya sido tradicionalmente cultivada y desarrollada por los agricultores en sus campos, o

ii) sea una variedad silvestre o autóctona sobre la cual los agricultores poseen un conocimiento tradicional ${ }^{134}$.

Estas precisiones conceptuales de la ley de India son primordiales para hacer realidad los derechos de los agricultores sobre el fitomejoramiento que han realizado desde tiempos inmemoriales, y de igual manera, para darles la participación en los beneficios que se deriven del acceso a plantas silvestres o autóctonas que ellos han conservado, por el conocimiento tradicional asociado a las mismas.

\section{Registro de variedades existentes}

Los requisitos exigidos para el registro de una nueva variedad vegetal son los establecidos en el Convenio upov: novedad, distinción, homogeneidad y estabilidad ${ }^{135}$. No obstante, la Ley de India de 2001 introduce una importantísima disposición que posibilita el registro de variedades existentes con el fin de permitir la inscripción de las variedades preservadas y/o desarrolladas por agricultores y comunidades campesinas, tribales o nativas. La diferencia fundamental con el UPOV es, en este punto, la no exigencia de novedad para facilitar el registro de las variedades existentes y hacer realidad los derechos consagrados en el CDB y el TIRFAA ${ }^{136}$.

En esta forma, la ley permite el registro de nuevas variedades pero también el de las ya existentes, para lo cual se propone desarrollar una documentación o base de datos de todas las variedades existentes, catalogando las variedades de los agricultores para asegurar la disponibilidad de semillas, incluso las registradas bajo el régimen de derechos de obtentor en el sentido upov, y su conservación.

133. The Protection of Plant Varieties and Farmers' Rights Act, 2001, sección 2, literal k). Traducción libre.

134. Ibíd., literal 1). Traducción libre.

135. Ibíd., sección 15, sub-sección (1).

136. Ibíd., sección 15, sub-sección (2). 


\section{Obligación de informar el origen genético del material}

En la solicitud de registro el obtentor debe informar sobre el origen o procedencia del material genético con base en el cual efectuó el fitomejoramiento ${ }^{137}$. Esta información es fundamental para asegurar la participación en los beneficios a la comunidad que ha preservado el material vegetal o planta sobre el cual se realizó el fitomejoramiento. En el evento de que el obtentor no cumpla con su obligación de revelar el origen del material genético que empleó para desarrollar la nueva variedad, se le negará el registro ${ }^{138}$.

\section{Tiempo de protección}

El tiempo máximo de vigencia del certificado de obtentor varía según la especie o variedad, así: para los árboles y vides, 18 años desde la fecha de registro de la variedad; para las demás especies o variedades, 15 años contados también desde la fecha en que se concede el registro. En el caso de variedad existente la duración máxima es de 15 años desde la fecha de notificación de esa variedad por el gobierno central de acuerdo con la Ley de Semillas de 1966, esto es, cuando se considere que la variedad reviste algún tipo de interés y se quiera asegurar su calidad ${ }^{139}$. Anualmente el obtentor debe pagar una tasa para el mantenimiento de su registro. Esta tasa se establece de acuerdo con las regalías devengadas por la nueva variedad en ese mismo periodo de tiempo anual. El certificado de obtentor confiere un derecho exclusivo para producir, vender, mercadear, distribuir, importar o exportar la nueva variedad ${ }^{140}$.

\section{Restricciones al registro de semillas $O G M$}

No se concede registro para la semilla que use tecnología terminator y/o cualquier tecnología que tenga restricciones genéticas si ponen en peligro la vida, la salud humana, animal o vegetal ${ }^{141}$.

\section{Recompensa por la conservación y mejora de variedades locales y silvestres}

Este es uno de los aspectos fundamentales e innovadores de la ley implementada en India: el reconocimiento a la constante actividad de conservación y fitomejo-

137. Ibíd., sección 18, sub-sección (1), literal (h).

138. Ibíd., sección 40.

139. Ibíd., sección 24, sub-sección (6).

140. Cfr. Santhy, V.; Vijaya Kumari, P. R.; Vishwanathan, A. y Deshmukh, R. K., Central Institute for Cotton Research Nagpur, CICR Technical Bulletin n. ${ }^{\circ}$. 38, 2009, p. 12. Traducción libre. Disponible en [www.cicr.org.in/pdf/legislation_seed_quality.pdf], recuperado el 29 de marzo de 2016.

141. The Protection of Plant Varieties and Farmers' Rights Act, 2001, sección 29. Traducción libre. 
ramiento que han realizado los agricultores y comunidades a lo largo del tiempo, no contentándose con una simple mención honorífica sino recompensando económicamente por esta contribución.

\section{9. (1) Notwithstanding anything contained in this Act}

[...] (iii) a farmer who is engaged in the conservation of genetic resources of land races and wild relatives of economic plants and their improvement through selection and preservation shall be entitled in the prescribed manner for recognition and reward from the Gene Fund.

Provided that material so selected and preserved has been used as donors of genes in varieties registrable under this Act;

39. (1) No obstante lo dispuesto en esta Ley

[...] (iii) A un agricultor que está comprometido en la conservación de los recursos genéticos de las variedades locales y silvestres, que tengan alguna aplicación o utilidad, y en su mejoramiento a través de la selección y preservación, se le deberá reconocer y recompensar por el Fondo de Genes.

Siempre y cuando ese material o variedad así seleccionada y preservada haya sido usada como donante de genes en variedades registrables bajo esta ley ${ }^{142}$.

El Fondo Nacional de Genes se financia con los beneficios que comparten los obtentores, las tasas de mantenimiento anual que cancelan de acuerdo con sus regalías y las demás contribuciones de organizaciones nacionales e internacionales. El Fondo distribuye los beneficios entre las comunidades reclamantes, recompensando por la preservación y uso sostenible de los recursos genéticos, teniendo también como objetivo fortalecer las capacidades de los consejos comunitarios rurales de administración, Panchayat, para ejecutar las medidas de preservación ${ }^{143}$.

\section{Derechos de los agricultores}

... un agricultor tendrá derecho a guardar, usar, sembrar, resembrar, intercambiar, compartir o vender su producto agrícola, incluso las semillas de una variedad protegida en virtud de esta Ley, en la misma forma a la que tenía derecho antes de la entrada en vigor de la presente Ley:

Sin embargo, el agricultor no tendrá derecho a vender semillas de marca de una variedad protegida bajo esta Ley [...] "[S]emilla de marca” significa cualquier semilla puesta en 
un paquete u otro envase y etiquetada de manera que indique que esta semilla es de una variedad protegida bajo esta Ley ${ }^{144}$.

La norma es de una claridad meridiana y está en un todo de acuerdo con lo dispuesto en el artículo 9 TIRFAA, sólo que es mucho más claro en cuanto a salvaguardar el derecho de paisanaje, "resembrar, intercambiar, compartir", incluso vender "las semillas de una variedad protegida".

Con igual lógica jurídica se prohíbe vender la semilla con la marca o denominación de la protegida bajo el régimen de derechos de obtentor. En otras palabras, es lícito vender la semilla "genérica" y está vedada su venta bajo la marca o denominación registrada, conciliando así el interés público con el privado.

\section{Compensación a la comunidad por su contribución al fitomejoramiento}

Las comunidades locales, nativas y/o campesinas, tienen el derecho a reclamar por su contribución al desarrollo de una variedad, y en caso favorable tendrán derecho a una compensación económica. La indemnización así reconocida "será depositada por el obtentor de la variedad en el Fondo de Genes" ${ }^{145}$.

\section{Licencia obligatoria}

En cualquier momento, pasados tres años contados a partir de la fecha de expedición del certificado de registro de una variedad, cualquier persona interesada podrá solicitar a la Autoridad que se le conceda una licencia obligatoria para usar la semilla o el material de propagación de la variedad porque no satisface la demanda o "la semilla u otro material de propagación de la variedad no está disponible al público a un precio razonable" 146 .

\section{Conclusiones}

La Ley de India de 2001 es un paradigma a seguir para los países en desarrollo y prueba que con entereza se puede equilibrar el interés privado con el beneficio social, conciliando la justa protección de los fitomejoradores con el derecho consuetudinario campesino a conservar, limpiar, guardar o almacenar semillas e intercambiarlas y venderlas en el mercado local. También recompensa la paciente labor de preservación y mejoramiento de plantas que durante siglos han efectuado las comunidades indígenas o nativas y campesinas.

144. The Protection of Plant Varieties and Farmers' Rights Act, 2001, sección 39, sub-sección (1), numeral (iv).

145. Ibíd., sección 41. Traducción libre.

146. Ibíd., sección 47, sub-sección (1). Traducción libre. 
No se entiende por qué esta ley es ignorada en los foros y eventos, incluso los académicos, donde expertos que deberían conocerla, omiten cualquier referencia a ella. ¿Será por el consabido argumento de que no hay alternativa distinta a la adhesión al upov versión 1991 ?

El Acta de 1978 ofrece la suficiente protección a los obtentores y otorga una discrecionalidad a los Estados en cuanto a su ámbito de aplicación, que debería preservarse sin importar lo que se diga en los controvertidos "acuerdos de promoción comercial", que en todo caso pueden revisarse. Téngase en cuenta que el Protocolo Modificatorio al TLC Colombia-Estados Unidos así lo autoriza ${ }^{147}$.

La versión upov de 1991 conculca los derechos de los agricultores y comunidades campesinas, cercenándolos y poniendo en peligro la economía campesina, más de siete millones de personas según el censo de 2005, que produce "el $70 \%$ de la comida, pese a que estamos importando 10 millones de toneladas en alimentos gracias a los $\operatorname{TLC}^{\prime \prime 148}$. Someterlos a comprar semillas para cada cultivo es empobrecerlos aún más y sacrificar la seguridad y la soberanía alimentarias.

Es incomprensible que el ICA a rajatabla quiera imponer las restricciones del upov 1991, en flagrante contradicción con lo dispuesto en el vigente artículo 26 de la Decisión 345 de 1993, mediante una interpretación que la desvirtúa.

Por último, reformar el artículo 27.3 literal b) ADPIC para hacerlo compatible con el CDB y el TIRFAA es una necesidad inaplazable, a menos que se pretenda seguir privilegiando el comercio y la propiedad intelectual por encima de la biodiversidad y los derechos humanos.

\section{REFERENCIAS ${ }^{\text {I49 }}$}

Liévano Aguirre, Indalecio. Los grandes conflictos sociales y económicos de nuestra historia, t. III, Bogotá, Nueva Prensa, 1960.

Monroy Rodríguez, Juan Carlos, Director de la investigación, Régimen de protección socio jurídica de los conocimientos tradicionales en Colombia, Bogotá, Universidad Externado de Colombia, Bogotá, 2006.

Nieto Arteta, Luis Eduardo. Ensayos sobre economía colombiana, Medellín, Oveja Negra, 1969.

Pachón, Manuel y Sánchez Ávila, Zoraida. El régimen andino de la propiedad industrial, Bogotá, Ediciones Jurídicas Gustavo Ibáñez, 1995.

RIefF, David. El oprobio del hambre. Alimentos, justicia y dinero en el siglo XXI, Bogotá, Taurus, 2016.

147. Ley 1166 de 2007, párrafo D, nuevo artículo 16.4, párrafo nuevo 3. Disponible en [www.secretariasenado.gov.co/senado/basedoc/ley_1166_2007.html], recuperado el 29 de marzo de 2016.

148. Molano Bravo, Alfredo. "El agua tibia”, en El Espectador, 16 de agosto de 2015, p. 41.

149. Las normas, jurisprudencia, documentos, textos y sitios web, están referenciados en notas al pie de página. 
Robledo del Castillo, Pablo Felipe, Director de la investigación. Los derechos del obtentor de variedades vegetales en Colombia, Bogotá, Universidad Externado de Colombia, 2006.

Santa, Eduardo. Rafael Uribe Uribe, Bogotá, Planeta, 1998.

Tirado Mejía, Álvaro. Introducción a la historia económica de Colombia, Medellín, La Carreta, 1976.

Toro Pérez, Catalina; Bravo, Elizabeth y Vélez, Germán (eds.). La ecología politica de la bioseguridad en América Latina, Bogotá, Universidad Nacional de Colombia, 2014.

Uribe Arbeláez, Martín. Propiedad Industrial, neoliberalismo y patente de la vida, Bogotá, Doctrina y Ley, 2002.

Uribe Arbeláez, Martín. La transformación de la Propiedad Intelectual, Bogotá, Doctrina y Ley, 2005. 